\title{
A column of one's own: putting women on the pages of the RAPI Journal,
} 1977- 1982

\section{Deanna Grant Smith}

QUT Business School

Queensland University of Technology

Deanna.grantsmith@qut.edu.au

\author{
Natalie Osborne \\ School of Environment \\ Griffith University
}

\begin{abstract}
Between 1977 and 1982, the Royal Australian Planning Institute (RAPI) Journal, the forebear of Australian Planner, featured a column dedicated to women and planning. The column, entitled Marion, sought to raise awareness, exchange information and stimulate discussion about issues relating to women and planning. The column highlighted discriminatory employment and planning practices including the absence of women in senior planning positions. It also considered issues associated with planning for women and the impact of planning on women's lives, particularly from an intersectional and international perspective. A clear link was made between the need for women in planning at all levels to undertake planning for and with women. Grounded in the gains made by the feminist movement, the column championed the unique needs of women in urban design and planning but situated these within the broader social challenges experienced by women around their lack of access to power, resources, education and decision-making. In this article, we use Virginia Woolf's feminist text, $A$ Room of One's Own, as a hermeneutical device for reviewing the Marion column, reflecting on the place of women in the pages of the journal of the RAPI Journal and in the planning profession, and documenting its legacy.
\end{abstract}

\section{Introduction}

As the second country in the world to give (non-Aboriginal) women the right to vote in 1902 (Ramirez, Soysal, and Shanahan 1997), Australia has a long-standing association with the protection and creation of women's rights. The early white feminist movement in Australia was concerned with suffrage, women's right to stand for parliamentary election, and women's protection from sexual exploitation. The second-wave of feminism in Australia during the 1960s to the early 1980s was concerned with confronting legal and social double standards, workplace discrimination and sexual harassment. It was in this period, 40 years ago in 1977, that the Royal Australian Planning Institute (RAPI) Journal (1958-1981), the forebear of this journal, Australian Planner (1983-), began a column dedicated to women and planning. The column, entitled Marion, was named for architect Marion Mahony Griffin, who despite having worked with Frank Lloyd Wright (Harrison 1983), is best remembered as the wife of architect Walter Burley Griffin. Penned by Mercia Ferrier, ${ }^{1}$ Marion sought to 'stimulate awareness of issues relating to women and planning and to generate an exchange of information, ideas and opinions' (Ferrier 1977a, 101). The column was motivated by the need to 'recognise women as a special client group, and ... [to] consider women in planning, or rather the lack of women in planning, a field in which decisions are made by a male dominated elite' (Ferrier 1977a, 101, emphasis in original). A total of 16 columns were published between 1977 and 1982 
(see Table 1).

In this article, we use Virginia Woolf's seminal text, A Room of One's Own, as a hermeneutical device for reviewing the Marion column and reflecting on the place of women both in the pages of the RAPI Journal and in the planning profession more generally. A Room of One's Own, first published in 1929, was based on a series of lectures exploring ideas of women as writers, which were delivered by Woolf at two women's colleges at Cambridge University the preceding year. The extended essay, which explores the historical and contextual contingencies of literary achievement, including women's access to education and knowledge, stridently argued for the need for both a literal and figural space for women writers within a literary tradition dominated by men. It also has dominant spatial themes invoking ideas of access to physical and intellectual space, making it relevant on many levels to the study of planning and more particularly on writings about planning and planners.

Drawing from the philosophy and themes outlined in A Room of One's Own, we developed an analytical frame through which to read Marion, as two early career feminist planning scholars in the twenty-first century. Following a brief methodological discussion, this paper follows the six chapter structure of $A$ Room of One's Own, with section titles drawn direction from quotes within the corresponding chapter of Woolf's literary work.

Table 1. Marion column, by issue and year.

\begin{tabular}{|l|c|c|c|c|c|c|}
\hline Year & 1977 & 1978 & 1979 & 1980 & 1981 & 1982 \\
\hline Columns & & $16(1)$ & No column & $18(1)$ & $\begin{array}{c}\text { No } \\
\text { column }\end{array}$ & $\begin{array}{c}\text { No } \\
\text { column }\end{array}$ \\
\cline { 2 - 7 } & $16(2)$ & $17(2)$ & $18(2)$ & $19(2)$ & $\begin{array}{c}\text { No } \\
\text { column }\end{array}$ \\
\cline { 2 - 7 } & $15(3)$ & $16(3)$ & $17(3)$ & $\begin{array}{c}\text { No } \\
\text { column }\end{array}$ & $19(3)$ & $20(3)$ \\
\cline { 2 - 7 } & $15(4)$ & $16(4)$ & $17(4)$ & $18(4)$ & $19(4)$ & \\
\hline
\end{tabular}

Feminist hermeneutics, literary critique and gynocritical method

The column description for Marion unashamedly grounds it in feminist critiques and emancipatory movements (Ferrier 1977b), and thus our analysis of it draws from feminist and critical methodologies. Our research approach is informed by feminist hermeneutics, feminist literary critique and gynocriticism. Hermeneutics, particularly feminist hermeneutics, can be used to revisit and 
reinterpret historical records (like Marion) in a way that centres the experiences of the marginalised it is a way to read 'anew' existing texts (Heinämaa 2016) through an emancipatory lens. Feminist hermeneutics also provides a way for us to help forgotten or marginalised works and voices resurface in the record (Heinämaa 2016).

Drawing also from feminist literary critique, we use $A$ Room of One's Own by Virginia Woolf as a hermeneutical device through which to structure our reading and (re)interpretation of Marion, and to reflect on the place of the column within the broader canon and contributions of the RAPI Journal. Schweickart $(2008,497)$ proposes that such critique needs to reflect on what 'it mean[s] for a woman, reading as a woman, to read literature written by a woman writing as a woman?' Responding to this call, we move beyond feminist critique which retains the patriarchy as its focus and combine feminist literary critique with gynocriticism, as the latter centres study on the woman as writer and the history, themes, imagery, ideology and genres of their writing while also foregrounding female experiences of reading (Nouri and Aziz Mohammad 2015; Showalter 1981; Stanford Friedman 1996). Gynocriticism recognises common denominators that unify women's experiences, based on oppression and otherness and foregrounds gender in analysis (Manoff 2003) but may also embrace an intersectional understanding of these experiences (Donovan 1984). Feminist criticism of this type is a political and polemic activity with the goal of not only interpreting literature but also seeking to change the world in so doing. Gynocriticism is rooted in cultural feminism and includes the literary work of Virginia Woolf within its ranks (Donovan 1984), making it a logical choice for this study.

This approach combining feminist hermeneutics, feminist literary critique and gynocriticism allows us to engage in a kind of hermeneutic conversation (Kinsella 2006) - to allow these two texts to 'speak' to one another through our interpretation and translation. Using a poetic text like $A$ Room of One's Own aids our (re)interpretation of the Marion column by engaging 'imaginative literary constructions that by virtue of the refiguration of possibilities, reconstruct reality and invite the reader to inhabit this projected world' (Viljoen 2016, 3). Finally, it gives our (re)interpretation a clear, situated stance from which our understanding is constructed, made visible in the structure of this essay.

Our process for developing this hermeneutic conversation began with an existing familiarity with A Room of One's Own, and pulling our own dog-eared and highlighted copies off our respective bookshelves. Individually, we read through the Marion body of work, and then set about reading both texts together, attempting a kind of cross-translation. Separately, we identified where we thought the authors were using a 'common language' (Kinsella 2006), and then compared and combined our interpretations. In this essay, we begin each section with an extract from Woolf to elucidate a particular theme or idea, and to frame the interpretation of Marion that follows, to show a kind of dialogue between these two texts. Of course, like any interpretation ours is situated and partial, and we must acknowledge how we have highlighted here what resonated for us. As Kinsella (2006) describes, through our interpretation we have provided 'intonation to the texts involved in the conversation' thus influencing how they will be understood. Therefore, this hermeneutic conversation is one between $A$ Room of One's Own, Marion, the authors and the reader. 


\section{How unpleasant it is to be locked out}

... and I thought how unpleasant it is to be locked out; and I thought how it is worse perhaps to be locked in; and, thinking of the safety and prosperity of the one sex and of the poverty and insecurity of the other and of the effect of tradition and of the lack of tradition upon the mind of a writer ... (Woolf 1929, 37)

In A Room of One's Own, the fictional narrator is denied access to the spaces of men. This rejection shapes her behaviours and over time, though tempted, restricts where she passes and where she seeks to enter for fear of further rebuff. The inaugural Marion

column stated that ' $[\mathrm{t}$ ]he purpose of this column is to stimulate awareness of issues relating to women and planning and to generate an exchange of information, ideas and opinions' and to draw critical attention to the fact that planning 'decisions are made by a male dominated elite' (Ferrier 1977a, 101). Indeed, Ferrier recounts $(1980 \mathrm{~d}, 6)$ that the inaugural contribution

was requested by the Honourary [sic] Editor and after that I was asked to write a regular column on planning and women. Quite a breakthrough in a very male dominated profession. Having a female Honourary Editor ... probably helped!

Issues covered in the inaugural column included a focus on the experiences of women in planning, notably the absence of women in planning positions and discriminatory employment practices. It also considered issues associated with planning for women and the impact of planning on women's lives, particularly from an intersectional perspective. A clear link was made between the need for women in planning to undertake planning for women.

Grounded in the gains made by the feminist movement, the Marion column championed what it classed as 'the special needs of women in urban design' but situated this within the broader challenges experienced by women around 'their lack of access to power, resources, education and decision making' more broadly (Ferrier 1977b, 139). Marion challenged Australian women to recognise the political processes associated with urban planning and to affect change through the political arena through pressure groups and voting.

\section{Those gentlemen who specialise in woman}

It seemed a pure waste of time to consult all those gentlemen who specialise in woman and her effect on whatever it may be - politics, children, wages, morality - numerous and learned as they are. One might as well leave their books unopened. (Woolf 1929, 46)

Much of the Marion column was dedicated to highlighting the findings of national and international reports and seminars dealing with the issue of women and planning, including without a hint of irony an address by a man on 'Women's Role in Planning Cities' (Ferrier 1977b, 139). According to Annette Kolodny $(1980,13)$, Virginia Woolf

quite properly anticipated the male reader's disposition to write off what he could not understand, aban- 
doning women's writings as offering 'not merely a difference of view, but a view that is weak, or trivial, or sentimental because it differs from his own'.

She is referring to the problem of male audience reception of the work of women which is focussed on women's concerns. Much as the need for this special issue of Australian Planner was subject to criticism by some of our colleagues, grounded in the denial that gender affects both planners' experiences in the profession and people's experiences in the built environment, Marion also reported on the widespread denial of discrimination against women in planning.

Ferrier (1979a, 179) recounts that despite evidence presented in the column and research reports, when RAPI Divisions across the nation were asked to comment on the state of women in planning the majority of Divisions claimed that there was no discrimination against women, 'at least no more so than in society in general'. There was 'outright denial of the existence of discrimination' against women in either employment or promotion within the planning profession and rejection of the suggestion that planning might perhaps benefit from a more balanced perspective (Ferrier 1979a, 179). Of a Division with no female members that vehemently rejected the existence of discrimination against women in their State's planning profession, Ferrier wryly notes that 'One can only assume that this was the considered judgement of an all-male committee within an exclusively male Division' (1979a, 179).

Kolodny $(1980,15)$ asks of the 'fate of the women writer whose competent reading community is composed only of members of her own sex?' She suggests that the texts of women present a dilemma for the male reader 'who, in opening the pages of a woman's book, finds himself entering a strange and unfamiliar world of symbolic significance' and female experience which he will then 'necessarily dismiss ... as undecipherable, meaningless, or trivial' (Kolodny 1980, 6- 7). These denials are thus rooted in both privilege and notions of epistemological authority. A Room of One's Own recounts the frustrations of failing to find accounts of women's experiences written by women, for authority over their own lived experiences was denied. They could be written about and objectified in analysis by those with authority to do so. They could not speak truth themselves, let alone others.

As Ferrier found, gendered analysis - let alone feminist analysis - is often met with denial, or insistence that any inequality needs to be quantifiably proven in a way that conforms to a particular epistemological hegemony; not coincidentally, the one that in and of itself is associated with and continues to uphold kyriarchal structures of privilege. As a result, contemporary accounts of discrimination remain whispered in the fear that a woman's account of her own experiences of gendered discrimination will not hold recognisable authority. Our personal experience has been that accounts of sexual harassment or incivility at conferences and congresses often go unreported, in part due to the lack of clarity of rights, responsibilities and avenues of redress available. That such events represent an important extension of the academic/professional workplace but are experienced differently by women (Settles and O'Connor 2014) makes them worthy of concern as these experiences may influence entry into and intentions to stay within an industry that in the past has been characterised as 'toxic', especially for women (PIA 2004, i). Shamefully, the prevalence of 
gentlemen who specialise in women to the exclusion of women's own perspectives continues. Perhaps the most egregious recent example was a 2016 International Women's Day event hosted by Public Transport Victoria on the theme of women in transport, featuring an all-male panel (Ingram, 2016).

\section{Practically she is completely insignificant}

A very queer, composite being thus emerges. Imaginatively she is of the highest importance; practically she is completely insignificant. (Woolf 1929, 66)

One might assume that for the readers of the RAPI Journal that the themes discussed in Marion and their gendered emphasis would have highlighted the absence of gendered analysis elsewhere in the journal and in planning practice more generally. Perhaps, however, the column may have had the perverse effect of allowing some to avoid engaging with these issues on the understanding that women's views were being represented. Furthermore, although the column reflected numerous times on the role that planning and urban policy could play in improving people's - especially women's lives, its status as a non-scholarly contribution to the journal may have worked to undermine its emancipatory goal. Because not only were women's issues partitioned, they may have been rendered less significant than their academic, evidence-based counterparts in the journal by being given lesser status. Valuable as the contribution of the Marion column was, it could not substitute for empirical feminist research, particularly if it was to influence practice and to disrupt hegemony. The 'strong feminist voice' (Steinmetz, Freestone, and Hendricks 2013, 282) presented in Marion did not appear to have the effect of increasing the presence of feminist research within the journal.

The feminist spatial planning politic advocated in the Marion column called for employment opportunities to be 'dispersed throughout the urban areas close to residential areas' (Ferrier 1978c, 100), a goal shared by more contemporary urban theories which focus on the neighbourhood scale. Women's employment has been, and continues to be, disproportionately affected by home and caring responsibilities (Gibb et al. 2014; Pocock, Charlesworth, and Chapman 2013). These are exacerbated by a range of planning policies. Marion critiqued the ways that masculinist urban theory and planning practice, such as land use planning and zoning regulations, enabled masculine mobilities and labour patterns to dominate decisions (Ferrier 1978c). The column elucidated the connection between spatial governance and the sex-based division of labour and how processes that produce urban space (re)produce social relationships. In particular, Ferrier highlighted how economic decisions, for example around industrial development, were blind to the employment needs of women. Indeed, Ferrier $(1978 a, 23)$ argued that 'the need for jobs for women is ignored as women are seen only as wives and mothers, subsumed under the title of "family"; matters of symbolic importance but undeserving of focused, practical attention. This subsumption and the spatial and political outcome of zoning laws thus work to reinforce the gendered public-private dichotomy and further render 'the woman' as insignificant, in effect 'seeing them inexpertly only in their role of servicing the family' (Ferrier 1976, 52) whilst also failing to acknowledge the value of that reproductive labour. 


\section{Blue stockings with an itch for scribbling}

It might be well to sneer at 'blue stockings with an itch for scribbling', but it could not be denied that they could put money in their purses. (Woolf 1929, 97)

Marion discussed how perceptions of women's capabilities and assumptions about them in the industry were limiting their professional development and opportunities as planners. The column provided evidence from Australia and elsewhere that women planners were actively discriminated against; they were underpaid, denied supervisory responsibilities, under-represented in the profession and in RAPI's membership ranks, and found it more difficult to find employment (Ferrier 1977a, 1978a, 1978c, 1979a). Those women amongst the ranks of planners were subject to sexism within the workplace and the professional. Ferrier $(1978 a, 23)$ cites a submission from a ratepayer following a series of public participation meetings conducted by a planning firm 'renowned for its lady planners':

I think it is a man's job to outline the aims and objectives of any planning ideas. This sort of job is not suitable for bits of girls, no matter how talented, willing, or enthusiastic they may be. A lot of matters and problems in relation to planning and work in this area could only be debated in very strong language and not suitable for the tender and sensitive ears of young women.

The column also reports on the poor representation of women at professional events. For example, the RAPI 18th Biennial Congress delegate list contained only 5 female participants compared to 120 male participants, though an editorial note suggests that 3 of these women could not attend (Ferrier 1978c).

Despite these incredible experiences, Ferrier remained optimistic about the capacity of the profession for change. This may reflect an understanding of planning as an inherently progressive and dynamic activity but one that is not immune from broader social, cultural and political forces. Ferrier generously conceded that planners cannot be held 'wholly responsible' for the spatial and professional subjugation of women (Ferrier 1976, 53). This is because, she argued, planners

rely on the underlying value and definition of sex roles. The structure of our society, and the political and social status of women, are such that it will take an overall economic and social change for them to be accorded complete equality. Moreover, only then will planners, in planning for 'people', do justice to women.

If 'lady planners' were to be recognised simply as planners, attitudinal, professional and societal change was required. This involved the need for male planners and community members to recognise the professional capacity and competence of women beyond exclusively women's interests and a disproportionate responsibility for managing relationships and social planning. It also required that when these women planners chose to raise feminist issues that these were not dismissed as sneer worthy and had a legitimate place within professional planning discussions and decisions. 


\section{The perennial interests of domesticity}

Also, I continued, looking down at the page again, it is becoming evident that women, like men, have other interests besides the perennial interests of domesticity. (Woolf 1929, 125)

Gender is often seen as being about women and therefore a matter for women (Fincher 2007). Reporting on the Marion column in the journal Women and Environments, Vale Dods (1980, 9) observes the range of gender issues covered, and that they were presented from the perspective of Ferrier as a student of planning, a planner, and as someone who could integrate her lived experience into reflections of planning, and use this as a filter to critique planning practices and urban environments. Indeed, the Marion column acknowledged the intersectionality of women's experiences in the built environment (Ferrier 1977a); that is that their experiences as women are also impacted by factors such as their ethnicity and class, and that women are also responsible for representing and advocating for issues which affect them as women as well as issues which affect children (another under-represented and under-considered group in planning) (Ferrier 1977b). The Marion column argued somewhat optimistically that

The many issues of social policy and planning which women understand from being at the 'other end' e.g., urban planning, child care and employment, would not be relegated to a low priority if more women were involved in planning. (Ferrier 1978a, 33)

Although this might reflect the interrelationship between women and children through women's (continued) disproportionate role in care and reproductive labour, this construction may also work to normalise, rather than critique, this dynamic, and may erase or elide the concerns of women independent of their relationships to others. While children remain the concern of women, rather than parents, their needs and interests will remain subordinate. If the needs of children were instead to be recognised as the responsibility of both parents, men would be equally implicated in addressing the interests of children in their planning decisions.

However, women planners have also traditionally been responsible for adopting a more care-full approach to planning. In the pages of the RAPI Journal, Paul Oppermann $(1960,17)$ suggested that 'civic and political leaders are inclined to listen with respect and trust to a poised, diplomatic, wellorganized woman Planner, feeling that women can speak with a special authority about the needs of people'. This view assumes that all women planners intuitively have a special interest in and ability and obligation to speak for others. It also presents a tension. Either failing to adhere to or meeting this standard may work to undermine the professional opportunities available to women planners. Excelling at this role may result in women planners not being seen as suitable for other planning roles and relegated to being 'merely' planners for women and experts in the issues faced by women and children. Thus if women adopt this role they are typecast by it, but if they fail to do so this may cast aspersions on both their femininity and professional value. Notwithstanding what this extract suggests about the performativity requirements of professional femininity in planning, it highlights the construction of the 'woman Planner' as Other and absolves male planners of the responsibility to 
think and act for Others. This in opposition to Woolf's exhortation that 'if one is a man, still the woman part of his brain must have effect' $(1929,148)$. This suggests that creating a professional culture of equality requires action and commitment from both male and female planners. For men doing so requires that they overcome the misogynist sense that they are diminished by femininity, and instead that their judgement as planners will be enhanced by embracing it.

Despite Opperman's claim, gender is not necessarily the best or most reliable indicator of concern for women's issues and does not guarantee a feminist agenda of social priorities' (Richards 1984, 449 cited in Whip 2003, 74). This tension, though not explicitly highlighted, can be seen in the reporting of the appointment of June Baghel as the first women to be a part-time member of the Victorian Town and Country Board. Mrs Baghel is reported in the Marion column as stating

The mood of the community was that, if possible, the new appointee should be a woman, but one who would represent not only the women generally but also the other interest groups ... I do not see myself representing 'women' or 'women's interests' - just people. (Ferrier 1978a, 23)

\section{The power to think for oneself}

A lock on the door means the power to think for one-self. (Woolf 1929,160$)$

The fictional narrator of $A$ Room of One's Own notes that men have access to higher levels of resources, sustenance, support and their own histories than women and that this disparity is due to the lower levels of patronage that women have traditionally enjoyed. As a result, rather than enjoying the privileges granted by the toils of others, women have had to work to create their own meagre gains. It was not through lack of hard work or ambition but rather a lack of power and privilege that women had little to bequeath to each other and upon which to build. Instead they must labour at structural change, to literally 'make bare walls out of the bare earth' (Woolf 1929, 35). Marion and the other journals dealing specifically with the women's issues which emerged at this time ${ }^{2}$ are examples of this labour.

The Marion column is important in both its focus and its historical context; ' $[u] n t i l$ the mid to late 1980s, feminist readings of urban issues in social science were sparse, internationally and in Australia' (Davison and Fincher 1989, 187); indeed, as a publication of the RAPI, the predominance of US literature and examples is noteworthy to the contemporary reader. The presence of the Marion column in the pri- mary journal of the Australian planning profession arguably provided a room of one's own and some measure of independence that enabled feminist analysis of the planning project and profession in a mainstream space. For the period of its run, the column created a space that did not have to continually justify its own existence. Instead, it could focus on engaging with gender and related issues, and advancing justice within the profession and Australian built environments. However, it is not enough to start but to continue.

The editorial note to the inaugural column expressed a deeply held hope that the column would 'obsolesce, rapidly' (Ferrier 1977a, 101). Such a desire was grounded in the faith that women's issues 
would become institutionalised and addressed over time for the benefit of all. But what is the legacy of Marion? Woolf $(1929,146)$ proposes that 'a woman writing thinks back through her mothers'. Marion as a cultural artefact has value in this regard as it is '[t]hanks to the toils of those obscure women in the past, of whom I wish we knew more' (Woolf 1929), that a generation of planners learned that so-called women's issues mattered and that their voices deserved to be heard. For reasons that remain unstated and unclear, Marion vanished from the pages of the RAPI Journal, without a farewell column or epitaph.

In A Room of One's Own, Virginia Woolf under- scores the importance of a history of women to negate their absence in current accounts. Although there has been little published in the RAPI Journal or Australian Planner in the years since the Marion column ended that adopts an explicitly gendered lens, ${ }^{3}$ it was a step towards creating the politics of presence (Phillips 1998) required to achieve the original aims of the column. In Woolf's terms Marion provided the room, if only temporarily. There have since been a number of notable pieces which document the contributions of women to Australian planning theory and practice and which apply a gendered lens to understanding the institutional of culture of the Australian planning profession, in particular. These include Whitzman, Nichols, and Perkovic's (2009) history of women in planning in Victoria, Robert Freestone's (1995) history of women in the Australian town planning movement between 1900 and 1950 and his co-authored biography of Freestone and Hanna (2007), and Steinmetz, Freestone, and Hendricks's (2013) account of women in planning in New South Wales, and Wendy Steele's (2008) essay in the Griffith Review on Leonie Sandercock, Ann Forsyth, Margo Huxley and Jean Hillier.

It has been argued that there is a direct relationship between women's political activism and progressive social policy (Sawer and Simms 1984). The Marion column was not blind to the structural and institutional reforms required and promoted a role for RAPI in advocating for women, and for those who experience disadvantage in the built environment. Quoting a report from the American Society of Planning Officials, the inaugural Marion column proposed '[j]ust as the women's movement maintains that the liberation of women will in fact liberate all of society from stereotypes sex, race, age and other roles ... attention to the changing needs of women will strengthen the whole planning process' (Ferrier 1977a, 101). Our review of the Marion column is akin to Kolodny's $(1980,15)$ 'rereading ... [of the] previously lost works' of female writers to raise 'perplexing questions as to the reasons for their disappearance from the canons of "major works"'. But it is insufficient that such a review simply note that little has changed or to relegate these writings to the place of anachronistic or overly optimistic feminist musings. Instead we take up the challenge presented by Ferrier to continue the tradition of questioning and critique.

With or without Marion as the platform, the struggle for advancing the rights of women and Others continues and it is our fervent hope that there will always be those within profession who will take up these challenges. Though this responsibility has been inconsistently embraced and acted on, this special issue of Australian Planner, itself an initiative of the Planning Institute of Australia (RAPI's successor), is a tacit acknowledgement of the need to ensure that the voices of 
Grant-Smith, D., \& Osborne, N. (2017). A column of one's own: Putting women on the pages of the RAPI journal, 19771982. Australian Planner, 54(1), 51-58. doi: 10.1080/07293682.2017.1297319

women are heard and highlighted within the planning profession, and that in doing so planning outcomes will be better for all.

\section{Notes}

1. Mercia Ferrier, a Fellow of the Planning Institute of Australia (PIA 2013), was an active member of the Queensland Divisional Committee for many years and formerly on the editorial board of the RAPI Jour- nal (Australian Planner 1983). She had connections with the School of Australian Environmental Studies, Griffith University (Ferrier 1983), was a former part- time lecturer at the Department of Regional and Town Planning, University of Queensland and later director at A lan Ferrier, Campbell and Associates (Australian Planner 1983). Mercia Ferrier was also the daughter of former Labor Prime Minister and dip- lomat Frank Forde and sister-in-law to former Queensland Governor, Leneen Forde (Hardman 1983; Lloyd and Saunders 2007).

2. Examples of journals emerging in this period include Women and Environments International Magazine founded in Canada in 1976 and Women's Studies International Forum founded in in 1978.

3. Notable exceptions include Bell (1990), Fincher (2003), Hannaford (2008), Rorke-Wickins and Wilson (2009) and Steinmetz, Freestone, and Hendricks (2013).

\section{Disclosure statement}

No potential conflict of interest was reported by the authors.

\section{References}

Australian Planner. 1983. "Mainly About Us: Editorial Board." 21 (2): 50. doi:10.1080/07293682.1983.9657079.

Bell, W. 1990. "Where Are the Women Planners?" Australian Planner 28 (1): 32-35. doi:10.1080/07293682. 1990.9657443.

Davison, G., and R. Fincher. 1989. "Urban Studies in Australia: A Road Map and Ways Ahead." Urban Policy and Research 16 (3): 183-197. doi:10.1080/08111149808727765.

Donovan, J. 1984. "Toward a Women's Poetics." Tulsa Studies in Women's Literature 3 (1/2): 98-110.

Ferrier, M. 1976. "Women, Post-stretton." Royal Australian Planning Institute Journal 14 (3-4): 52-53. doi:10.1080/00049999.1976.9657994.

Ferrier, M. 1977a. "Marion: Women and Planning." Royal Australian Planning Institute Journal 15 (3): 101. doi:10. 1080/00049999.1977.9656536.

Ferrier, M. 1977b. "Marion." Royal Australian Planning Institute Journal 15 (4): 139. doi:10.1080/00049999.1977.9656558.

Ferrier, M. 1978a. "Marion." Royal Australian Planning Institute Journal 16 (1): 23-24. doi:10.1080/00049999.1978.9656592.

Ferrier, M. 1978b. "Marion." Royal Australian Planning Institute Journal 16 (2):46-47. doi:10.1080/00049999.1978.9656605.

Ferrier, M. 1978c. "Marion: Feminists Unaware of Urban Issues." Royal Australian Planning Institute Journal 16 (3): 99-100. doi:10.1080/00049999.1978.9656640.

Ferrier, M. 1978d. "Marion: RAPI Notices Women." Royal Australian Planning Institute Journal 16 (4): 134. doi:10. 1080/00049999.1978.9656660. 
Grant-Smith, D., \& Osborne, N. (2017). A column of one's own: Putting women on the pages of the RAPI journal, 19771982. Australian Planner, 54(1), 51-58. doi: 10.1080/07293682.2017.1297319

Ferrier, M. 1979a. "Marion: Blinkered Males Deny Bias." Royal Australian Planning Institute Journal 17 (2): 179 180. doi:10.1080/00049999.1979.9656712.

Ferrier, M. 1979b. "Marion: The Child As Second Class Citizen." Royal Australian Planning Institute Journal 17 (3): 203-204. doi:10.1080/00049999.1979.9656727.

Ferrier, M. 1979c. "Marion." Royal Australian Planning Institute Journal 17 (4): 235. doi:10.1080/00049999.1979.9656744.

Ferrier, M. 1980a. "Marion." Royal Australian Planning Institute Journal 18 (1): 23-24. doi:10.1080/00049999. 1980.9656774.

Ferrier, M. 1980b. "Marion." Royal Australian Planning Institute Journal 18 (2): 65. doi:10.1080/00049999.1980. 9656802.

Ferrier, M. 1980c. "Marion." Royal Australian Planning Institute Journal 18 (4): 133-134. doi:10.1080/00049999. 1980.9656841.

Ferrier, M. 1980d. "Column on Planning and Women." Women and Environments 4 (1/2): 6.

Ferrier, M. 1981a. "Marion." Royal Australian Planning Institute Journal 19 (2): 86-87. doi:10.1080/00049999. 1981.9656913.

Ferrier, M. 1981b. "Marion." Royal Australian Planning Institute Journal 19 (3): 120-121. doi:10.1080/00049999. 1981.9658024.

Ferrier, M. 1981c. "Marion." Royal Australian Planning Institute Journal 19 (4): 146-147. doi:10.1080/00049999. 1981.9658040.

Ferrier, M. 1982. "Marion: Women in Cities." Royal Australian Planning Institute Journal 20 (3): 131-132. doi:10.1080/07293682.1982.9656966.

Ferrier, M. 1983. "Sexism in Australian Cities: Barrier to Employment Opportunities." Women's Studies International Forum 6 (1): 73-84. doi:10.1016/0277-5395(83)90088-2.

Fincher, R. 2003. "Planning Cities of Diversity, Difference and Encounter." Australian Planner 40 (1): 55-58. doi:10.1080/07293682.2003.9995252.

Fincher, R. 2007. "Space, Gender and Institutions in Processes Creating Difference." Gender, Space and Society 14 (1): 5-27. doi:10.1080/09663690601122150.

Freestone, R. 1995. "Women in the Australian Town Planning Movement 1900-1950." Planning Perspectives 19 (3): 257-277. doi:10.1080/02665439508725823.

Freestone, R., and B. Hanna. 2007. Florence Taylor's Hats: Designing, Building and Editing Sydney. Ultimo: Halstead Press.

Gibb, S. J., D. M. Fergusson, J. L. Horwood, and J. M. Boden. 2014. "The Effects of Parenthood on Workforce Participation and Income for Men and Women." Journal of Family and Economic Issues 35 (1): 14-26. doi:10.1007/s10834-013-9353-4.

Hannaford, J. 2008. "Demographic Change and the Lives of Women: What is the Planner's Role?" Australian Planner 45 (3): 20-21. doi:10.1080/07293682.2008.9982670.

Hardman, M. 1983. "Gordon Below Franklin." Australian Planner 21 (1): 21. doi:10.1080/07293682.1983.9657044. Harrison, P. 1983. "Griffin, Marion Lucy Mahony (1871-1961)." In Australian Dictionary of Biography, Volume 9. National Centre of Biography, Australian National University. Accessed September 25 2016. http://adb.anu. edu.au/biography/griffin-marion-lucy-mahony-7102/ text11115.

Heinämaa, S. 2016. "Hermeneutics and Feminist Philosophy." In Blackwell Companion to Hermeneutics, edited by 
Grant-Smith, D., \& Osborne, N. (2017). A column of one's own: Putting women on the pages of the RAPI journal, 19771982. Australian Planner, 54(1), 51-58. doi: 10.1080/07293682.2017.1297319

N. Keane, and C. Lawn, 557-572. West Sussex: John Wiley and Sons.

Ingram, L. 2016. "The International Women's Day Panel ... With NO Women." Daily Mail Australia, March 9. http:// www.dailymail.co.uk/femail/article-3483358/International-Women-s-Day-event-Public-Transport- Victoriafeatures-panel-no-women-it.html.

Kinsella, E. A. 2006. "Hermeneutics and Critical Hermeneutics: Exploring Possibilities Within the Art of Interpretation." Forum: Qualitative Social Research 7 (3): Art. 19. http://www.qualitative-research.net/index.php/ fqs/article/view/145/320.

Kolodny, A. 1980. "Dancing Through the Minefield: Some Observations on the Theory, Practice and Politics of a Feminist Literary Criticism." Feminist Studies 6 (1): 1-25.

Lloyd, N., and M. Saunders. 2007. "Forde, Francis Michael (Frank) (1890-1983)." In Australian Dictionary of Biography, Volume 17. National Centre of Biography, Australian National University. Accessed October 15 2016.http://adb.anu.edu.au/biography/forde-francis-michael-frank-12504/text22477.

Manoff, M. 2003. "Tools for Feminist and Women's Studies Scholars in Literature: Issues and Problems." In Bibliography in Literature, Folklore, Language and Linguistics: Essays on the Status of the Field, edited by D. W. Foster and J. R. Kelly, 48-69. Jefferson, NC: McFarland.

Nouri, A., and F. Aziz Mohammad. 2015. "A Study of Carter's Wolf-Alice Based on Sholwater's Gynocriticism." International Letters of Social and Humanistic Sciences 48: 1-8. doi:10.18052/www.scipress. com/ILSHS.48.1.

Oppermann, P. 1960. "Should You Be A: City and Regional Planner?" Royal Australian Planning Institute Journal 1 (6): 16-18. doi:10.1080/00049999.1960.11509592.

Phillips, A. 1998. The Politics of Presence. Oxford: Oxford University Press.

PIA (Planning Institute of Australia). 2004. Findings and Recommendations of the National Inquiry Into Planning Education and Employment. Canberra, ACT: Planning Institute of Australia.

PIA. 2013. Planning Institute of Australia Queensland Awards for Planning Excellence Commemorative Book. Planning Institute of Australia. https://www.planning. org.au/documents/item/5734.

Pocock, B., S. Charlesworth, and J. Chapman. 2013. "Work- family and Work-life Pressures in Australia: Advancing Gender Equality in 'Good Times'?" International Journal of Sociology and Social Policy 33 (9/10): 594-612. doi:10. 1108/IJSSP-11-2012-0100.

Ramirez, F. O., Y. Soysal, and S. Shanahan. 1997. "The Changing Logic of Political Citizenship: Cross-national Acquisition of Women's Suffrage Rights, 1890 to 1990." American Sociological Review 62 (5): 735-745. http:// www.jstor.org/stable/2657357.

Rorke-Wickins, C., and L. Wilson. 2009. "Gender in Planning Education." Australian Planner 46 (3): $40-45$. doi:10.1080/07293682.2009.10753407.

Sawer, M., and M. Simms. 1984. A Woman's Place: Women and Politics in Australia. Sydney: G. Allen and Unwin. Schweickart, P. 2008. "Reading Ourselves: Towards a Feminist Theory of Reading." In Modern Criticism and Theory: A Reader. 3rd ed. edited by D. Lodge and N. Wood, 484-505. Oxon: Routledge.

Settles, I. H., and R. C. O'Connor. 2014. "Incivility at Academic Conferences: Gender Differences and the Mediating Role of Climate." Sex Roles 71 (1-2): 71-82. doi:10.1007/s11199-014-0355-y.

Showalter, E. 1981. "Feminist Criticism in the Wilderness." Critical Inquiry 8 (22): 179-205. http://www.jstor.org/ stable/1343159.

Stanford Friedman, S. 1996. "'Beyond' Gynocriticism and Gynesis: The Geographics of Identity and the Future of Feminist Criticism." Tulsa Studies in Women's Literature 15 (1): 13-40.

Steele, W. 2008. "City Dreamers." Griffith Review 20: 73-80. 
Grant-Smith, D., \& Osborne, N. (2017). A column of one's own: Putting women on the pages of the RAPI journal, 19771982. Australian Planner, 54(1), 51-58. doi: 10.1080/07293682.2017.1297319

Steinmetz, C., R. Freestone, and L. Hendricks. 2013. "Women, Professionalism and Leadership in State Government Planning in New South Wales." Australia Planner 50 (4): 282-292. doi:10.1080/07293682.2012.748084.

Vale Dods, K. 1980. "Women and Planning: Australia." Women and Environments 4 (1/2): 9-10.

Viljoen, A. 2016. "Theological Imagination as Hermeneutical Device: Exploring the Hermeneutical Contribution of an Imaginal Engagement with the Text." HTS Teologiese Studies/Theological Studies 72 (4): a3172. doi:10.4102/ hts.v72i4.3172.

Whip, P. 2003. "The 1996 Australian Federal Election and its Aftermath: A Case for Equal Gender Representation." Australian Feminist Studies 18 (40): 73-97. doi:10.1080/0816464022000056385.

Whitzman, C., D. Nichols, and J. Perkovic. 2009. From Accidental Planner to Agent Provocateur: 60 Years of Women in Victorian Planning. Melbourne: Women's Planning Network.

Woolf, V. 1929. A Room of One's Own. London: Hogarth. 